\title{
Usability Testing: A Case Study
}

\section{Janet Chisman, Karen Diller, and Sharon Walbridge}

\begin{abstract}
Usability testing is a technique for identifying difficulty that individuals may have using a product. Usability tests of the Washington State University (WSU) Libraries' online public access catalog (OPAC), Article Indexes, Full Text, More, and Other Library Catalogs sections revealed problem areas. A task force used test findings to recommend solutions that led to the participation of the working group involved in designing search screens, the libraries' User Education Department, and Innovative Interfaces Inc., the OPAC vendor. Solutions are currently being implemented.
\end{abstract}

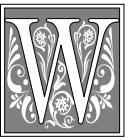

ashington State University (WSU) is a multicampus institution with an Innovative Interfaces Inc. (III) integrated system that serves both WSU and Eastern Washington University (EWU). This shared catalog creates considerable ambiguity for its users. Even if the catalog were not shared with another institution, there is enough complexity within the WSU environment to create user confusion, with six libraries on the Pullman campus and four extended campus libraries located around the state.

In January 1998, WSU implemented the Web-based version of the III OPAC. This OPAC, named Griffin, is used on all WSU campuses and at EWU. In the five months spent designing the Web OPAC (WebPac), it became evident that there were many opinions, but few data, on how it should look and work to make it easy to use. The III WebPac has enough flexibility that decisions regarding screen design, button text, order of information, and other usability questions were under debate. Some at WSU were concerned that decisions were being made based on "gut feelings," anecdotal experiences, scattered observations, and so on. What did the WSU team really know about user perceptions and understanding?

During the design stage, the September/October 1997 issue of the OCLC Newsletter ran a series of short articles on usability testing at OCLC. ${ }^{1-3}$ This was especially timely as the institution struggled with customizing the WebPac. The idea of usability testing could go a long way toward providing information that could be used to make informed choices and decisions on WebPac design. Improved screen displays and help features, easier movement among screens, and clearer instructions could result in a more userfriendly catalog, empowering the user and freeing the librarian from dealing with the more routine questions about the catalog. Problems not within the librarians' direct control would be communicated to III directly, to the Innovative Users Group, and to the libraries' User Edu-

Janet Chisman is the Systems Librarian at Washington State University Libraries-Pullman; e-mail: chisman@wsu.edu. Karen Diller is the Assistant Campus Librarian at Washington State University Libraries-Vancouver; e-mail: diller@vancouver.wsu.edu. Sharon Walbridge is the Assistant Director for Technical Services at Washington State University Libraries-Pullman; e-mail: walbridg@wsu.edu. 
cation Department so that solutions could be worked on from a variety of fronts.

Three interested librarians, two from the Pullman campus and one from the Vancouver campus, began serious discussions of WebPac usability testing in February 1998. The timing was fortuitous because one of the team members was planning to travel to OCLC for a conference. Arrangements were made to visit with OCLC Usability Lab Director Mike Prasse, who was very generous with his time. He offered a tour of the OCLC usability lab, shared history of the OCLC effort and a description of the process, offered practical advice, and even allowed the visiting librarian to observe an actual test.

Prior to the OCLC visit, the WSU team had conducted a literature search for articles specifically on usability testing of library Web-based catalogs. Although the team did not find any articles on the topic, it did discover The Handbook of Usability Testing by Jeffrey Rubin, which became the team's bible. ${ }^{4}$ Rubin's book offered practical advice and helped lay out a road map to follow. By adapting the structure and concepts discussed by Rubin, it was possible to develop a purpose statement, a test plan, a task list, and the beginnings of a test. Drafts of those went to OCLC with the visiting librarian. Here again, Prasse was generous with his comments and suggestions, and noted that OCLC uses Joseph S. Dumas and Janice Redish's Practical Guide to Usability Testing as a resource. ${ }^{5}$ Some of the important points that Prasse made were:

- Limit the test to an hour.

- Emphasize and reemphasize that it is the system that is being tested, not the person.

- Keep the test limited and focused; don't try to cover too much.

It should be noted that the OCLC usability lab is high tech. The WSU libraries did not have access to such a facility nor the funds to develop one. The team looked for a low-tech alternative. Prasse had noted that videotaping the participant and the computer screen would be nice, but that a simple tape recording of the participant's responses would be an acceptable bare-bones approach. The WSU team decided to have two persons observe each test participant and to taperecord his or her comments during the session.

\section{Purpose and Preparation}

The purpose of the usability testing was simple: to test how easily users could navigate the Web-based Griffin catalog and whether they understood what they were seeing. At Pullman, the team also wanted to test whether library patrons could find the electronic indexes and links to non-WSU library catalogs from the WSU Libraries Gateway shown in figure 1.

One of the first steps was to develop a test set of questions for the Griffin test, which would be the first test. A pretest on the WebPac questions done by the Vancouver team member affirmed one of the most important things that Prasse had shared, namely, to reemphasize repeatedly that it is the system that is being tested and not the person. OCLC has this motto posted in large letters in its lab, and the team posted the same words in its test room. The pretest also helped the team refine some of the questions.

Both literature and Prasse indicated that eight participants would identify 80 percent of the problems users might have with the system. The team devised a screening questionnaire to help identify a range of users based on gender, age, library, and computer experience. It decided to do the initial Griffin test with eight participants on the Pullman campus, four novice computer/library users and four expert computer/library users, and four participants on the Vancouver campus.

At Pullman, an advertisement for volunteers was run in the student newspaper. The team felt that paying test participants $\$ 10$ for their time would add legitimacy to the effort. The library administration agreed to provide up to $\$ 200$. The advertisement yielded twenty-nine ex- 


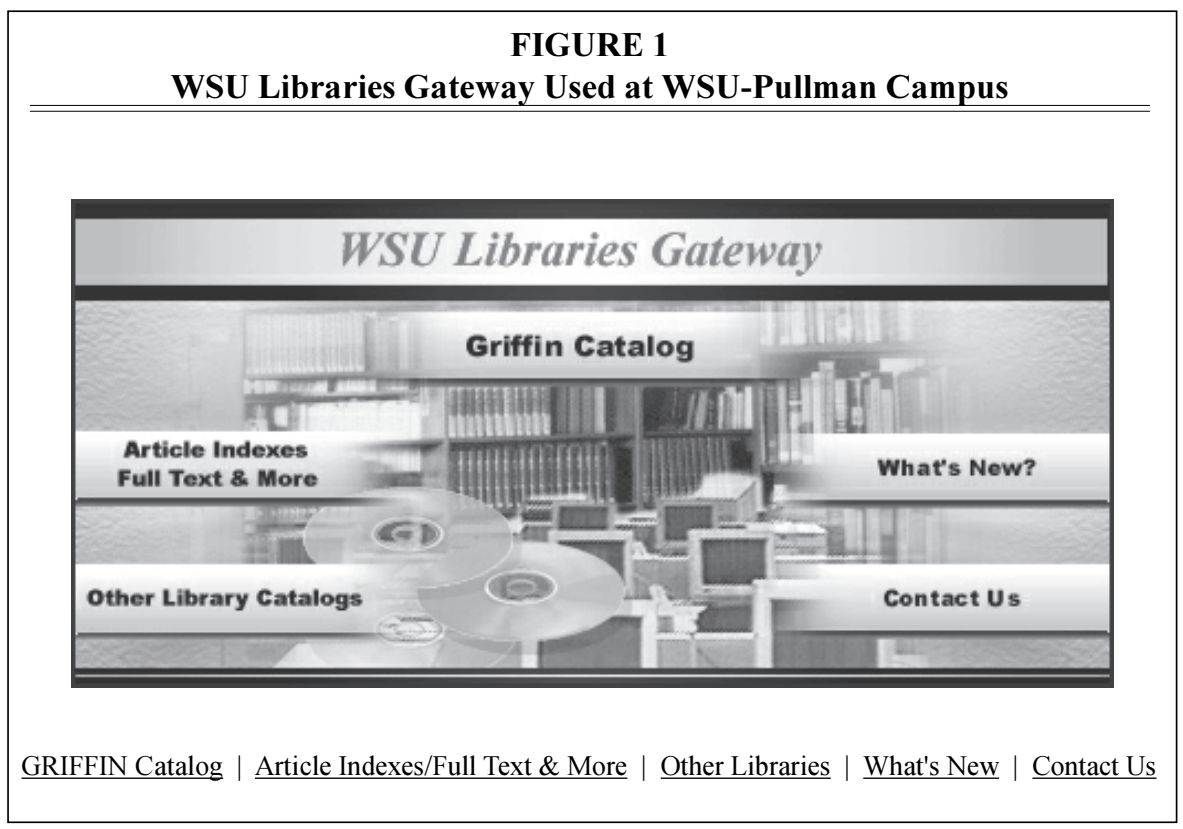

pressions of interest. The team decided to draw participants for the electronic indexes/non-WSU catalogs test from this pool as well. At Vancouver, volunteers responded to flyers posted around campus and only the Griffin usability test was conducted.

Each volunteer was asked to complete the screening questionnaire. Three questions formed the nucleus for decisions relative to whether the person was a novice or an expert computer/library user and with the level of experience he or she had with computers, with the WSU Libraries, and with the Internet. Other questions on age, gender, and university status helped create demographic diversity among the potential test participants.

WSU requires a formal review of procedures whenever human subjects are used in research. Because the team planned to ask students to complete a series of tasks, the usability testing fell into this category of research. Thus, the team filed a detailed human subject form for review by the Institutional Review Board, complete with consent forms and copies of the tests and procedures being used. The Institutional Review Board approved the testing.
In preparing for the actual test sessions, several checklists were compiled as recommended in the Rubin book (see figure 2). Equipment was located, tapes bought, and a data collection form designed. The data collection form listed the participant tasks, with room below each to record success, false starts, beginning time, and ending time.

\section{The Tests}

At Pullman, the team met each volunteer at the entrance of the library because the office where the tests were to be held was not easy to find. Each session was opened by reading a standard greeting and setting the scene. Team members explained that the same opening statement was being read to each participant to ensure that everyone heard the same set of directions.

The Griffin WebPac test featured fortyfive questions. Was this too many? Perhaps, because the test seemed grueling for both test participants and observers. Even though the test was completed within the hour maximum suggested by Prasse, the team came away feeling that a smaller number of questions would be more appropriate. Initially, the observers played the script very straight, trying not to com- 


\section{FIGURE 2 Usability Checklists*}

Checklist 1: Six weeks before the test-May 1, 1998 Decide what to tell volunteers.

Decide what data to collect.

Performance data

Preference data

Develop data collection method and manual data collection form p. 165.

Develop an orientation script.

Develop debriefing outline (pp. 211, 245).

Checklist 2: Three weeks before the test-May 26, 1998

Take the test.

Check all equipment and the testing environment.

Get copies of background questionnaire ready.

Advertise for participants.

Administer background questionnaire.

Choose participants based on questionnaire responses.

Schedule test times, leaving adequate time between tests to debrief.

Checklist 3: One day before the test-June 12, 1998

Check that the product is working.

Assemble all written test materials and data collection forms.

Double-check test environment and equipment.

Contact participants to remind them of test date, time and place.

Checklist 4: Day of the test-June 15-19, 1998

Scan the checklist.

Prepare mentally.

Greet the participant.

Have the participant complete and sign any preliminary documents.

Read the orientation scripts and set the stage.

Move to the testing area and prepare to test.

Establish protocol for observers in the room.

Distribute written task scenario(s) to participant.

Have the participant complete the posttest questionnaires.

Debrief the participant (pp. 211, 245).

Thank the participant, provide remuneration, and show the participant out.

Organize data collection and observation sheets.

Monitors debrief.

Prepare for the next participant.

Checklist 5 following the tests-July 1998

Transform data into findings and recommendations.

Make needed changes to the system.

*Page numbers refer to pages in Rubin. 
ment at all. However, by a sort of unspoken agreement, the observers eventually "loosened up" and made comments aimed at reassuring the test participants. The mood-lightening comments were found to be helpful in keeping the participants relaxed and the test moving along.

Each observer recorded search strategy, comments made by the test participant, observations about the participant's responses, success, and the time to complete the task. After ten tests were completed (seven at WSU-Pullman and three at WSU-Vancouver), the data were compiled to form a picture of the ease or difficulty of each task.

One of the suggestions made by both Rubin and Prasse was that observers debrief participants soon after the test session and then compare notes on what had occurred. During the first series of tests, the team chose not to debrief the participants but later regretted its decision. Discussing the sessions soon after each was completed would be especially helpful in defining what constituted a success. For example, if the user found something, but not in the most efficient way, was the effort considered successful?

The second test dealing with electronic indexes and non-WSU library catalogs was administered at WSU-Pullman only. By this time, the observers with seven Griffin tests to their credit were more relaxed and willing to offer suggestions when participants ran into difficulty. This, along with fewer tasks (fourteen instead of forty-five), made the second test less intense and intimidating. The final questions led to valuable discussions between observers and participants.

\section{Results and Discussion: What Was Learned about the WSU WebPac}

The results of the testing showed that the WSU team's categories of novice and expert computer/library user did not correlate to a participant's ability to use the WebPac. The profiles for WSU-Pullman campus participants are given in table 1 , and the results of the WebPac test are presented in table 2.
The most important thing the team learned is that many students know how to move from screen to screen using WebPac buttons, browser features, and hot-linked, clickable text. With a Webbased interface, experienced Internet users can get around quite easily. But this is not always beneficial. For example, users may feel comfortable with the use of scroll-down menus for changing search options. But when using a shortcut such as this, they do not see examples of the search format to be used in each search option (i.e., using last name first for an author search). Typing in a search in the wrong format led some of the participants to conclude that the item they were looking for was not in the WSU libraries' cata$\log$.

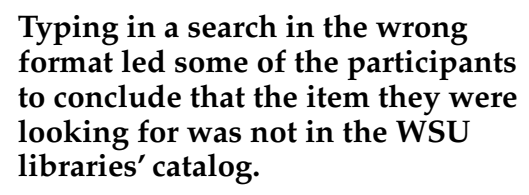

Many users are so supremely confident in their searching that when they do not find something, they immediately conclude that it is not owned by the WSU libraries. It does not occur to them that they may have searched incorrectly and that they could/should try another search.

Users often do not understand concepts and are unable to interpret content. Participants did not recognize the difference between what is available in the WebPac and what is available in the Article Indexes, Full Text, and More sections. How to get this idea of structure, of what is where, across effectively is still an open issue. The idea of a title search meaning the title of the periodical and not the title of the article was a problem. Participants were provided a reference to a periodical article and asked whether the library owned it. They proceeded to search article author, article title, and finally periodical title. Obviously, the only hit would come from the search on the periodical title. Unfortunately, this was often discovered by trial and error. But for eight of 


\begin{tabular}{|c|c|c|c|}
\hline \multicolumn{4}{|c|}{$\begin{array}{c}\text { TABLE } 1 \\
\text { WSU-Pullman Campus Participant Profiles } \\
\text { Results of Screening Questionnaires }\end{array}$} \\
\hline Questions & No. & Questions & No. \\
\hline 1. Experience with a computer & & $\begin{array}{l}\text { 5. Preferred learning style } \\
\text {-Trial and error }\end{array}$ & 6 \\
\hline -None & 1 & —Consult with others & 0 \\
\hline -One-two years & 2 & -Read documentation & 2 \\
\hline -More than two years & 4 & & \\
\hline & & 7. Employed by the libraries & 0 \\
\hline $\begin{array}{l}\text { 2. Status at WSU } \\
\text {-Undergraduate student }\end{array}$ & 3 & 8. WSU library experience & \\
\hline -Graduate student & 3 & -First-time user & 1 \\
\hline —Postgraduate student & & — Occasional use (once a month) & 2 \\
\hline —Faculty member & & —Frequent use (once a week) & 4 \\
\hline —Staff member & & — Had a library instruction class & 0 \\
\hline -Other & 1 & & \\
\hline & & 9. Internet access/use & \\
\hline 3. Age category & & —World Wide Web & 6 \\
\hline$-18-22$ & 3 & -Telnet & 5 \\
\hline$-23-30$ & 2 & —E-mail & 7 \\
\hline -over 30 & 2 & & \\
\hline & & 10. Internet Use & \\
\hline 4. Gender & & —Never or rarely & 1 \\
\hline —Female & 4 & -Occasional use (once a week) & 1 \\
\hline -Male & 3 & -Frequent use (once a day) & 5 \\
\hline
\end{tabular}

the ten participants, even trial and error did not lead to the information because they did not recognize the answer when they had it.

This result led to another key finding. Users of the WebPac do not understand serials, cannot identify them in a browse display containing both books and serials, and cannot navigate through complex serial information. How to find current check-in records, how to locate different formats such as microfilm, how to determine which libraries have what volumes is a mystery to most students. Clearly, libraries need to do a better job of explaining this, and the OPACs must be more helpful in aiding users to find this important information.

Understanding the concept that Griffin includes the library holdings of two institutions is not difficult. However, users did not always understand how to search for items on a specific WSU campus. With six libraries on the WSU campus at Pullman and four campus libraries around the state, participants found it difficult to determine what library they were currently searching and how to search only one library at a time.

Other discoveries included:

1. The limiting feature, where users can narrow by date, type of material, and so on was not readily understood. Most users were able to find the limiting function but were unable to use it effectively. Sometimes they found the exact thing they needed but did not recognize it. Especially troublesome was limiting by serial format. Participants overlooked this serial option in a drop-down list even when looking at it. The use of MARC format terminology in drop-down lists is extremely "user-unfriendly" in limiting searches. How would any student know 


\begin{tabular}{|c|c|c|}
\hline \multicolumn{3}{|c|}{$\begin{array}{c}\text { TABLE } 2 \\
\text { Griffin WebPac Test } \\
\mathbf{N}=\mathbf{1 0} \\
\end{array}$} \\
\hline Tasks & Questions & $\%$ Problems \\
\hline 1. Book by title at particular location & $\begin{array}{l}\text { Does Washington State University-Vancouver campus library have a copy } \\
\text { of Gone with the Wind? }\end{array}$ & 40 \\
\hline 2. Book in 1 at EWU & Does Eastern Washington University library have a copy of Gone with the Wind? & 20 \\
\hline $\begin{array}{l}\text { 3. Book by title, libraries holding } \\
\text { 4. Omit }\end{array}$ & Which of the WSU libraries have Hamlet by Shakespeare? & 30 \\
\hline 5. Periodical from a given citation & $\begin{array}{l}\text { Does WSU libraries own the following: Albertson, John. } \\
\text { Supermarkets in the Northwest. Advertising Age 68: 12-25 (1997). }\end{array}$ & 80 \\
\hline 6. Material by corporate author & Find material in the libraries by IBM. & 60 \\
\hline 7. Book by author and display complete recol & $\begin{array}{l}\text { Find books by Laurie Garrett at any WSU location. Look at the detailed } \\
\text { information for one of these books. }\end{array}$ & 20 \\
\hline 8. Books about a person & Find books written about Toni Morrison. & 40 \\
\hline 9. Book by author/title & Do WSU Pullman libraries have a book called Guns, germs, and steel by Diamond? & 30 \\
\hline 10. Periodical by title & Do WSU Pullman libraries have a copy of the periodical Audubon? & 30 \\
\hline $\begin{array}{l}\text { 11. Particular library owns what years } \\
\text { of periodical located in } 10 \text {. }\end{array}$ & What years does Owen library have of this periodical? & 50 \\
\hline 12. Current issue of periodical located in 10 & Did the Owen library receive the Sept/Oct 1997 issue? & 80 \\
\hline $\begin{array}{l}\text { 13. Particular volume of periodical located } \\
\text { on shelf }\end{array}$ & Is volume 94 (1992) of Audubon on the shelf at the Owen library? & 50 \\
\hline 14. Government document by title & Do the WSU libraries own the government document, Domestic Price Directory? & 20 \\
\hline 15. Call number browse from detailed display & Locate the titles of other items shelved near this government document. & 40 \\
\hline 16. ISSN search & $\begin{array}{l}\text { Does the library subscribe to a ournal with the ISSN } \\
\text { (International Standard Serial Number) of 0002-9114? }\end{array}$ & 10 \\
\hline $\begin{array}{l}\text { 17. Keyword search books at particular } \\
\text { location, display detailed record }\end{array}$ & $\begin{array}{l}\text { Locate books at WSU-Pullman on the use of steroids by athletes. Look at a } \\
\text { detailed record for one of these books. }\end{array}$ & 30 \\
\hline
\end{tabular}




\section{TABLE 2}

\section{Griffin WebPac Test (cont.)}

\begin{tabular}{|c|c|c|}
\hline Tasks & Questions & $\%$ Problems \\
\hline 18. Subject heading for more items & $\begin{array}{l}\text { Using only the information on the screen and a mouse click, find more items } \\
\text { on the use of steroids by athletes. }\end{array}$ & 50 \\
\hline 19. Call number search given gov't doc number & $\begin{array}{l}\text { Check the Griffin Catalog to see if there is an item available with the call } \\
\text { number HE 1.2:Ad } 7 / 2 \text {. }\end{array}$ & 60 \\
\hline 20. Course reserve material & What material has Lynn Levy put in the library for her English 402 students to use? & 30 \\
\hline 21. Pseudonym search & $\begin{array}{l}\text { Look up the author Evans, Marian. Read the screen and find a listing of } \\
\text { books by this author. }\end{array}$ & 50 \\
\hline 22. Navigate from title to author search & $\begin{array}{l}\text { What do you do if you have chosen a title search and then discover you } \\
\text { really want to do an author search? }\end{array}$ & 0 \\
\hline 23. Navigate from title to call number search\# & $\begin{array}{l}\text { What do you do if you have chosen a title search and then } \\
\text { discover you really want to do a call number search? }\end{array}$ & 0 \\
\hline 24. Limit result list to periodical & Choose the first item in the list. Limit this resulting list to periodicals only. & 66 \\
\hline 25. Title in microform & Is this title available in microform? & 22 \\
\hline 26. Title in paper copy & Is this title available in paper copy? & 56 \\
\hline 27. Go to online & Go to the online version. & 56 \\
\hline 28. Main menu & Return to the main Griffin catalog search page. & 11 \\
\hline 29. Image database* & Do a subject heading search for juarez, benito. Find a portrait and display it. & 56 \\
\hline 30. LC call number search & Locate this book in the catalog DF 275. W92. & 50 \\
\hline 31. Status of book & Is this book checked out, or will you find it in the library? & 50 \\
\hline 32. Periodical search & Locate a copy of Nature (this is a scientific ournal [periodical]) & 25 \\
\hline 33. Keyword search & Do a keyword search on steroids. & 25 \\
\hline 34. Sort by date & Put the resulting list in order with the newest displaying first. & 12 \\
\hline 35. Scope to particular location & Return to your original search on steroids. Are any of these items at WSU-Vancouver? & 0 \\
\hline 36. Limit by language! & Return to your original search on steroids. Are any of these items in German? & 37 \\
\hline 37. Limit to periodicals & Return to your original search on steroids. Are any of these items journals (periodicals)? & 71 \\
\hline
\end{tabular}




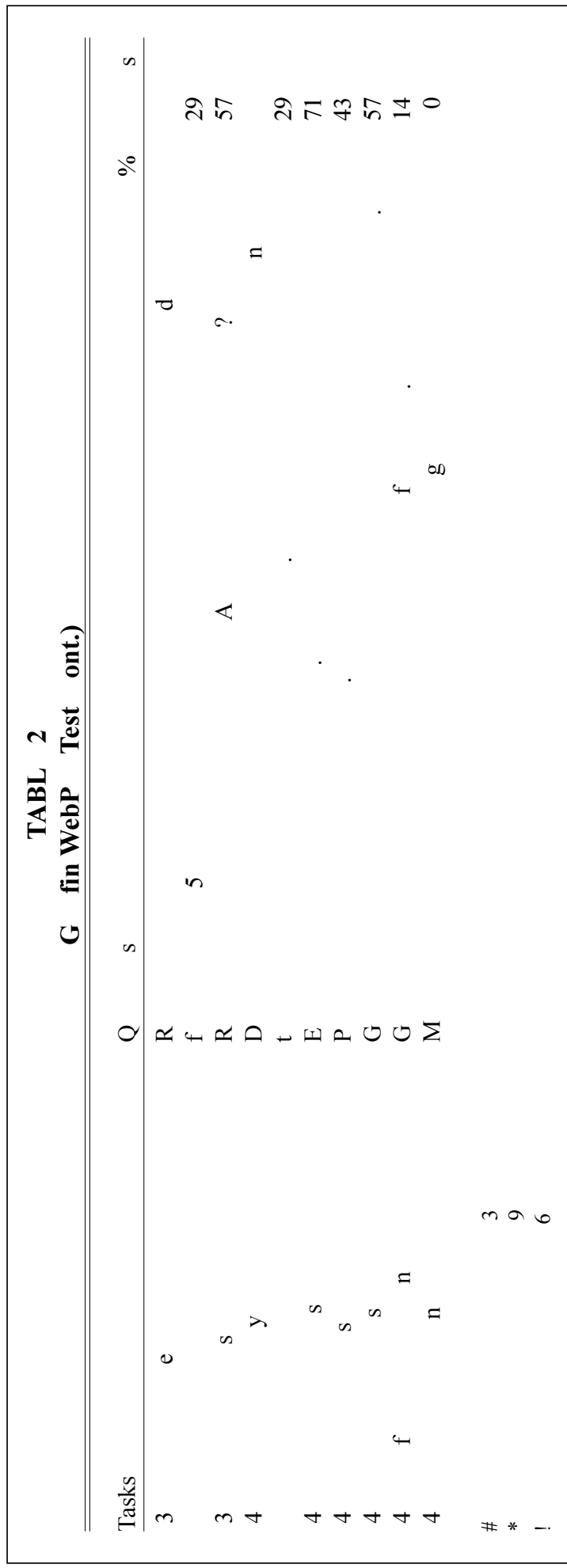

that the abbreviation proj medium (projected medium) is where to locate a video?

2. Users do not understand cross-references. For example, one question dealt with a pseudonym. The III system message appears to be straightforward. It indicates that the heading is not used and that users should search under the correct form. Although it even offers the option to "click here" to do the proper search, half the participants did not understand.

3. Users do not understand the use of multiple call number schemes in the library. Most of the books in the WSU libraries are classified in the Library of Congress scheme. Unfortunately, WSU libraries also have materials in Dewey, SuDoc, and a local government document scheme called Jackson. In Griffin, there are separate search buttons for Dewey, LC, SuDoc, ISSN, and local call numbers, as well as a search button for miscellaneous number searches. Under each type of call number search, examples of the call number pattern help users distinguish the types of call numbers. The test revealed that to the user, many of these patterns looked the same, which rendered the examples meaningless. Often users did not even take note of these examples, which are available only after choosing a call number type. Some users guessed that local meant any call number used locally. Some guessed correctly that when you are clearly searching a U.S. document, you should use the US Doc search button. One user wisely noted that he never had to search by call number because he never had that information when he came to find something in the library. 


\section{Results and Discussion: What Was Learned about Article Indexes/Other Library Catalogs Sections}

The second test, conducted only at WSUPullman, focused on electronic indexes and access to non-WSU library catalogs. The team scheduled eight participants, but only six of them kept their appointments. The results are shown in table 3 . The team already knew from a question in the WebPac test that students had difficulty understanding the difference between the bibliographic online catalog and where to find online article citations and full text.

Two of the test participants did not choose the Article Indexes, Full Text, and More sections of Griffin from the gateway page. For them to answer the remaining questions, they had to be told how to get to this page. Five of the six participants could not locate a nursing index that was listed in the medicine category. They chose the correct category but then scanned too quickly to notice the word nursing in the subheading under CINAHL (Cumulative Index to Nursing and Allied Health Literature). However, there is a lot of text on the page and it became obvious that this needed to be changed. Participants did better locating the index covering literature and linguistics. This may have been the result of getting used to the layout of the subject category table. Participants did notice database coverage in terms of dates included, although three later commented that they were unsure what the phrase "dates of coverage" actually meant. One participant did not locate the indexes asked about. This may have happened because he seemed to skip the first four or five questions to find one he wanted to try.

Only half the participants found the alphabetical list of databases. One participant later noted that she thought it was an alphabetical list of the titles covered in a particular database. This indicates that better labeling is needed. Participants did not notice the full-text designation in the alphabetic database list. When asked whether a database contained full text, they clicked on the database and read the description from the database Web site. Users were able to find the Encyclopaedia Britannica and to search and navigate it fairly well. It is located in a category labeled "Encyclopedias, Dictionaries and Almanacs," so the choice was obvious.

There was a problem locating the link to the Center for Research Libraries cata$\log$. This is in a section of the WSU Libraries Gateway labeled "Other Library Catalogs." Because there are many libraries at WSU, it was unclear what the label actually meant. For many library patrons, the library they use most often is the "only" library and anything else would be "other." Only half the participants could locate the "Restrictions on use" information. Obviously, these pages must be modified to make that information more readily available.

Suggestions that arose from questions 12-14, which dealt with the amount of information in the subject category listings, importance of providing log-on instructions, and the arrangement of the alphabetical list, included:

- A separate list of full-text databases would help.

- Make the full-text icon more obvious.

- How important are coverage dates? In some databases, they could be critical and in others insignificant.

- Descriptions are too wordy. One participant suggested they be put in a bulleted list format.

- Repeating information in the database description and then in the actual database is unnecessary.

- Screens are not too busy; they have clean background and have no "glitzy" graphics.

\section{Results and Discussion: What Was Learned about the Process}

When the test participants actually arrived and performed the tasks, the team found that its determination of novice and expert computer/library users was not always accurate. In fact, to make an accurate determination of novice or expert 


\section{TABLE 3}

\section{Article Indexes/Other Library Catalogs Test}

$$
\mathbf{N}=\mathbf{6}
$$

Question $\%$ Problem

1. From the WSU Libraries Gateway page, go to the page where you expect to find information on topics that have been published in periodicals (also known as serials or journals).

2. Using the subject category table of Article Indexes/Full Text \& More items:

2a. Locate an index to the nursing literature.

$2 \mathrm{~b}$. What other topics does this nursing index cover?

2c. Locate an index covering literature and linguistics.

$2 \mathrm{~d}$. What dates does it cover?

3. Go to the alphabetical list of Article Indexes/Full Text \& More. 50

3a. Is there any full-text information in the Agricola database? $\quad 50$

3b. Is there any full-text information in IDEAL?

4. Return to the page with the subject categories for Article Indexes/Full Text \& More.

4a. Find an encyclopedia article on drums and the American Civil War.

4b. Return to the Griffin catalog from the encyclopedia.

5. Return to the WSU Libraries Gateway page.

6. Go to the Center for Research Libraries catalog and log-in as if you were going to use the catalog.

7. Return to the WSU Libraries Gateway page.

8. Go the page with information on Article Indexes/Full Text \& More.

9. Click on the Restrictions on use link located below the table. Assume you have been denied access to ERIC, an education database. Go to the page where you would send a message to find out how to get a password and/or authorization to access ERIC.

10. Return to the page with the Restrictions on use link.

11. What is WorldCat?

11a. How often is it updated?

$11 \mathrm{~b}$. Who produces it?

$\begin{array}{lll} & \text { Possible } & \\ \text { Question } & \text { Responses } & \text { No. }\end{array}$

12. Return to the page with the subject categories for Article Indexes/Full Text \& More.

12a. Choose General/Multidisciplinary.

Read some of the database descriptions. Is there too much information here?

Yes

No

No response

$12 \mathrm{~b}$. If you think there is too much information,

Description what would you leave out? Please put an $\mathrm{X}$ by what you would omit.

13. Do you think the LOGON INSTRUCTIONS

Dates of coverage

Full text or index

Yes

No

No response

Alphabetical by column Alphabetical by row No response 
computer/library users in the future, it would be necessary to design a more intensive screening process.

After the tests, it became obvious that there is value in having observers in a separate room as occurs in the OCLC usability test lab. Observers can feel free to discuss what the test participant is experiencing and decide whether they want or need to help the user. Some test participants may have been uncomfortable with two observers watching them, although no one really complained or seemed unduly bothered. This aspect of testing was probably ameliorated as the observers themselves loosened up.

Test participants who are not native English speakers had difficulty with the questions.

Several of the test participants were young students, and observers noted that some of them were impatient. Several did not read instructions completely. This is especially problematic when questions build on previous ones. Thus, it is preferable not to have questions that build on one another. Test participants who are not native English speakers had difficulty with the questions. Because their participation was especially useful, the team recommends straightforward questions free of jargon or popular idiomatic expressions. For example, one of the questions in the second series of tests asked the user to find a database that covers nursing literature. The first test participant for whom English was not the native language, keyed in on the word literature in the question and went to the Modern Language Association (MLA) database where literature is included in the description.

It is advisable to check questions right up to test time when testing a database that is dynamic. For example, one question tested the user's knowledge of checking other locations for a book title that was not held on the Pullman campus. By the time the test was administered, the title had been cataloged for Pullman.
Finally, it is inevitable that some people will fail to show up for the test. Testers should plan for a 15 percent no-show rate. In addition, scheduling is one of the most time-consuming parts of testing and is easiest to do with participants who had e-mail.

\section{Implementation}

The results of the usability tests were turned over to a group responsible for overseeing development of the Webbased OPAC. This group reviewed all the areas where participants encountered difficulty in using the online catalog. For the Griffin WebPac test, they developed a table with task, problem, name of the individual responsible, and action to be taken (see table 4). The team is in the process of working on solutions that are within its local control; it will be submitting a series of enhancement requests to III. WSU's User Education Department has received a list of problem areas that will need to be included in instructional sessions. WebPac developers are working on making the recommended changes under local control.

As a result of the electronic indexes/ non-WSU library catalogs test at Pullman, the alphabetical list was changed to a drop-down menu from a table format. Descriptions in the subject category sections have been shortened, and information is presented in a bulleted format. The "Log-on Instructions" and "Alternative Connections" columns have been eliminated and a column on restrictions on use added. The label for "Other Library Catalogs" remains unchanged for the moment.

\section{Will WSU Do More Usability Testing?}

Needless to say, the team participants in the usability testing are true believers in its value. However, the process is intensive and takes time to prepare and execute. As more people become involved, the workload can be shared. Ideally, usability testing will occur naturally at any point when substantive changes are being made to the catalog. 
TABLE 4

Griffin Online Catalog-Results to Actions

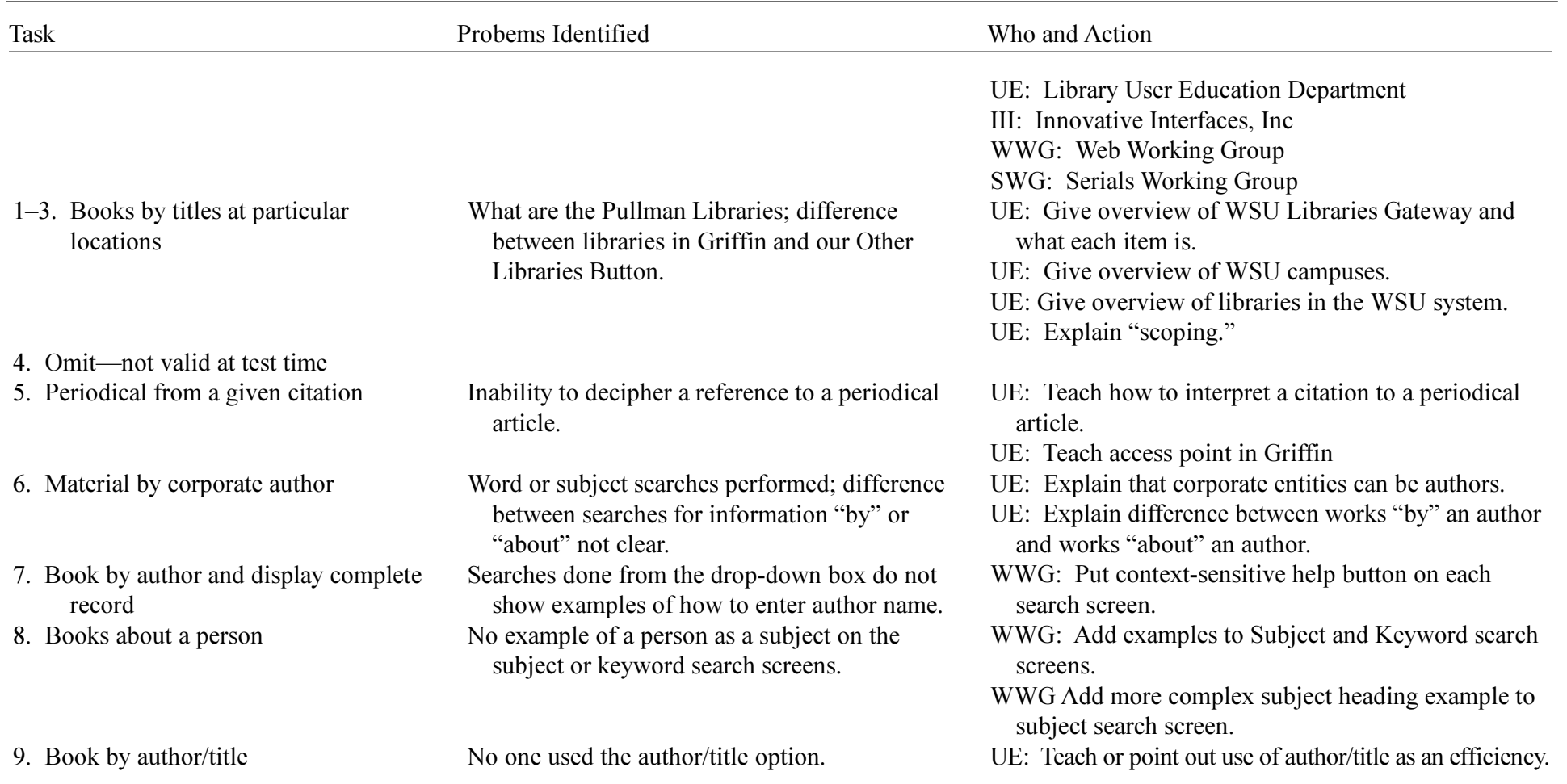




\begin{tabular}{|c|c|c|}
\hline \multicolumn{3}{|c|}{$\begin{array}{c}\text { TABLE } 4 \text { (cont.) } \\
\text { Griffin Online Catalog - Results to Actions } \\
\end{array}$} \\
\hline Task & Probems Identified & Who and Action \\
\hline 10. Periodical by title & $\begin{array}{l}\text { No one could recognize a periodical from the } \\
\text { browse display list resulting from the title } \\
\text { search. }\end{array}$ & $\begin{array}{l}\text { WWG: Provide access to a periodical title search } \\
\text { option. } \\
\text { UE: Teach terminology of serials — periodicals, } \\
\text { journals, magazines, newspapers. }\end{array}$ \\
\hline $\begin{array}{l}\text { 11. Particular library owns what years } \\
\text { of periodical in } 10\end{array}$ & $\begin{array}{l}\text { Complex location listings and inability to } \\
\text { decipher item records/summary statement. }\end{array}$ & $\begin{array}{l}\text { UE: Develop instruction approaches to explain } \\
\text { information on serials screen for questions } 11-13 \text {. } \\
\text { SWG: Review summary holdings statement format to } \\
\text { see if it can be simplified. }\end{array}$ \\
\hline $\begin{array}{l}\text { 12. Current issue of periodical located } \\
\text { in } 10\end{array}$ & Cannot locate check-in record. & $\begin{array}{l}\text { III: Make "Latest Received" hotlink more evident and/ } \\
\text { or re-label. } \\
\text { UE: See question } 11 \text {. }\end{array}$ \\
\hline $\begin{array}{l}\text { 13. Particular volume of periodical } \\
\text { located in } 10\end{array}$ & $\begin{array}{l}\text { Cannot decipher item records, don't know what } \\
\text { they are. }\end{array}$ & UE: See question 11. \\
\hline 14. Government document by title & None. & None. \\
\hline $\begin{array}{l}\text { 15. Call number browse from detailed } \\
\text { display }\end{array}$ & Did not notice that call number is a hotlink. & UE: Note in classes what the call number hotlink does. \\
\hline 16. ISSN search & None. & None. \\
\hline
\end{tabular}




\begin{tabular}{|c|c|c|}
\hline \multicolumn{3}{|c|}{$\begin{array}{c}\text { TABLE } 4 \text { (cont.) } \\
\text { Griffin Online Catalog - Results to Actions }\end{array}$} \\
\hline Task & Probems Identified & Who and Action \\
\hline $\begin{array}{l}\text { 17. Search books at particular location } \\
\text { on a topic, display detailed record }\end{array}$ & $\begin{array}{l}\text { Entering search statement; problems with word } \\
\text { vs. subject searching. }\end{array}$ & $\begin{array}{l}\text { WWG: Put mouse overlays on each button main } \\
\text { Griffin search screen. } \\
\text { WWG: Change Subject Headings button to ready LC } \\
\text { Subjects Only or ...? } \\
\text { WWG: Provide mouse overlays on subjects: "Use } \\
\text { ONLY for known Library of Congress subject } \\
\text { headings." } \\
\text { WWG: Re-label subject radio button to LC Subject. } \\
\text { WWG: Put help buttons on each search screen. } \\
\text { WWG: Use more complex subject examples. } \\
\text { WWG: Add corporate example. }\end{array}$ \\
\hline 18. Subject heading for more items & $\begin{array}{l}\text { Did not locate official, hotlinked subject } \\
\text { heading in the record. }\end{array}$ & $\begin{array}{l}\text { UE: Teach search strategy of keyword search then } \\
\text { click on subject headings in "best" items found. }\end{array}$ \\
\hline $\begin{array}{l}\text { 19. Call number search given gov't doc } \\
\text { number }\end{array}$ & $\begin{array}{l}\text { Don't know which type of call number to } \\
\text { search; don't recognize pattern from } \\
\text { examples. }\end{array}$ & $\begin{array}{l}\text { WWG: Change order of call \# buttons: LC, Dewey, } \\
\text { U.S. Docs in first row then ISSN, Local, Misc. in } \\
\text { second. } \\
\text { WWG: Put mouse overlays to define each call number } \\
\text { button. } \\
\text { WWG: Find a new label for Local. }\end{array}$ \\
\hline 20. Course reserve material & $\begin{array}{l}\text { No course reserve buttons when scoped to } \\
\text { entire catalog. }\end{array}$ & $\begin{array}{l}\text { WWG: Add course reserve buttons to entire catalog } \\
\text { and "WSU all locations" scope. }\end{array}$ \\
\hline 21. Pseudonym search & See reference message is not understood. & $\begin{array}{l}\text { III: Reword the message to something like: "For items } \\
\text { on XXX use XXX." }\end{array}$ \\
\hline 22. Navigate from title to author search & None. & None. \\
\hline $\begin{array}{l}\text { 23. Navigate from title to call number } \\
\text { search }\end{array}$ & None. & None. \\
\hline
\end{tabular}




\begin{tabular}{|c|c|c|}
\hline \multicolumn{3}{|c|}{$\begin{array}{l}\text { TABLE } 4 \text { (cont.) } \\
\text { Griffin Online Catalog - Results to Actions } \\
\end{array}$} \\
\hline Task & Probems Identified & Who and Action \\
\hline 24. Limit result list to periodical & $\begin{array}{l}\text { Limit/Sort not noticed. Words in drop-down } \\
\text { box are jargon. }\end{array}$ & $\begin{array}{l}\text { WWG: Provide a journal title search option. } \\
\text { III: Use understandable terminology as labels within } \\
\text { drop-down box of the Limit/Sort. }\end{array}$ \\
\hline 25. Title in microform & $\begin{array}{l}\text { Did not notice microform after title in browse } \\
\text { displays. }\end{array}$ & $\begin{array}{l}\text { WWG: Talk to Bib Control about inconsistency of } \\
\text { microform displaying after titles in browse list. }\end{array}$ \\
\hline 26. Title in paper copy & Paper is the default format and so not indicated. & None. \\
\hline 27. Go to online & $\begin{array}{l}\text { Did not notice hotlinks; messages very } \\
\text { confusing; multiple links and only one } \\
\text { works. }\end{array}$ & $\begin{array}{l}\text { WWG: Work with EWU and Bib Control to simplify } \\
\text { hotlinks. } \\
\text { WWG: Work with Bib Control to simplify wording } \\
\text { displaying as call number for online resources. }\end{array}$ \\
\hline 28. Main menu & None. & None. \\
\hline 29. Image database & $\begin{array}{l}\text { Hotlink to portrait not found; correct record not } \\
\text { chosen from subject browse listing; click on } \\
\text { call number and get into browse; don't } \\
\text { follow instructions. }\end{array}$ & WWG: Purchase III image database. \\
\hline 30. LC call number search & $\begin{array}{l}\text { Unable to recognize call number type so cannot } \\
\text { choose correct search. }\end{array}$ & $\begin{array}{l}\text { WWG: See actions in question } 19 \text {. Possibly develop } \\
\text { intermediate page from one call number button. This } \\
\text { page would give explanation and examples of every } \\
\text { call number type. }\end{array}$ \\
\hline 31. Status of book & None. & None. \\
\hline 32. Periodical search & Cannot pick out the serial in a browse display. & WWG: See actions in question 19. \\
\hline 33. Keyword search & Not following instructions. & None. \\
\hline 34. Sort by date & Don't see limit/sort button. & For questions $34-39$ \\
\hline 35. Scope to particular location & Don't see limit/sort button. & $\begin{array}{l}\text { UE: Alert users to limit/sort option. } \\
\text { UE: See actions in question } 33 \text {. }\end{array}$ \\
\hline
\end{tabular}




\begin{tabular}{|c|c|c|}
\hline \multicolumn{3}{|c|}{$\begin{array}{c}\text { TABLE } 4 \text { (cont.) } \\
\text { Griffin Online Catalog - Results to Actions } \\
\end{array}$} \\
\hline Task & Probems Identified & Who and Action \\
\hline 36. Limit by language. & Don’t see limit/sort button. & UE: See actions in question 33. \\
\hline 37. Limit to periodicals & $\begin{array}{l}\text { Terminology not understandable on sort labels } \\
\text { and within the drop-down box. }\end{array}$ & See actions in questions 24 and 33. \\
\hline 38. Limit by date & None. & None. \\
\hline 39. Limit to videos & $\begin{array}{l}\text { Terminology not understandable on sort labels } \\
\text { and within the drop-down box. }\end{array}$ & See actions in question 24. \\
\hline 40. Extended display & Not known what extended button does. & $\begin{array}{l}\text { UE Teach use of extended display for viewing date and } \\
\text { location. }\end{array}$ \\
\hline 41. E-mail three items & $\begin{array}{l}\text { Concept of marking and saving records to } \\
\text { create export list not understood. Save } \\
\text { marked records button only seen if scroll } \\
\text { down; not clear that user needs to choose } \\
\text { display option as well as e-mail; display } \\
\text { options not clear. }\end{array}$ & $\begin{array}{l}\text { UE: Explain concept of "export." } \\
\text { III: Improve export screen. }\end{array}$ \\
\hline 42. Print three items & $\begin{array}{l}\text { Concept of marking and saving records to } \\
\text { create an export list not understood. Save } \\
\text { marked records button only seen if scroll } \\
\text { down. }\end{array}$ & See actions in question 41. \\
\hline 43. Periodical articles & $\begin{array}{l}\text { Concept of what is and is not in Griffin is not } \\
\text { clear. }\end{array}$ & $\begin{array}{l}\text { UE: Explain difference between what is in Griffin vs. } \\
\text { article indexes. } \\
\text { WWG: Put mouse overlays on WSU Libraries } \\
\text { Gateway. } \\
\text { WWG: Review size and placement of buttons on WSU } \\
\text { Libraries Gateway }\end{array}$ \\
\hline 44. Griffin catalog button & None. & None. \\
\hline 45. Online suggestion & None. & None. \\
\hline
\end{tabular}


To integrate usability testing naturally into library procedures, budget support is necessary. A token payment to test participants helps with recruiting and legitimizing the process. Payment for all equipment and materials also should be part of the budget. It is unnecessary to commit great sums of money here; establishing a modest budget for usability testing has a tremendous return on investment.

The MSW team offers the following simple words of advice to anyone who wants to do usability testing:

- Begin now!

- Test early and test often.

- Keep the process simple and straightforward.

- Keep the tests narrow in focus.

- Do not try to learn too much in one test.

- Pay the test participants in some way.
- Debrief promptly after each test session.

- Communicate findings to system developers, user education instructors, public service librarians, and the system vendor.

WSU-Vancouver has already completed another round of testing of its library Web site. The team there used several different methods to attain data on how the site should be organized and what should be on it. Another project is under way at WSU-Pullman to test the usability of its library Web site. This testing will include the usability test format described here as well as card sort, category membership, and an online survey. The card sort and category membership tests will be similar to those already completed at the pioneering WSU-Vancouver campus library. Yes, WSU is in this for the long haul.

\section{Notes}

1. Bob Murphy, “Usability Testing," OCLC Newsletter 229 (Sept/Oct. 1997): 21-23.

2. "Usability Testing Started in OCLC Office of Research," OCLC Newsletter 229 (Sept/Oct. 1997): 24-25.

3. Lois Yoakam, "Writers Test Documentation to Determine Users' Needs," OCLC Newsletter 229 (Sept/Oct. 1997): 27.

4. Jeffrey Rubin, Handbook of Usability Testing: How to Plan, Design, and Conduct Effective Tests (New York: Wiley, 1994).

5. Joseph S. Dumas and Janice Redish, A Practical Guide to Usability Testing (Norwood, N.J.: Ablex, 1993). 